\title{
1 Effects of invasion level of Prosopis juliflora on 2 native species diversity and regeneration in Afar region, Northeast Ethiopia
}

\author{
Wakshum Shiferaw
}

Arba Minch University, College of Agricultural Sciences, Natural Resources Management Correspondence:waaqsh@yahoo.com

Abstract: The study aimed to assess (i) the effects of Prosopis juliflora invasion on the diversity of plant species, and floristic composition at Awash Fentale and the Amibara districts of the Afar region and (ii) the effects of $P$. juliflora invasion on the regeneration potential of native woody species. Sample collection was performed in habitats of $P$. juliflora thicket, $P$. juliflora mixed with native species stands, non-invaded woodlands, and open grazing lands. A stratified random sampling technique was used for data collection. Among species of plants, the highest proportion of species, $87(27.4 \%)$, was recorded under non-invaded woodlands, but the lowest proportion of species, 70 (22\%), was recorded under open grazing lands. The invasion level of $P$. juliflora caused significantly reduced Shannon diversity index. The mean values of Shannon diversity index and species richness under $P$. juliflora mixed with native species $\left(H^{\prime}=2.22, R=14\right)$ and non-invaded woodlands $\left(H^{\prime}=2.23, R=13\right)$ were significantly higher than $P$. juliflora thicket $\left(H^{\prime}=1.96, R=12\right)$ and open grazing lands $\left(H^{\prime}=1.84, R=10\right)$. In this study, 102 trees ha- $^{-1}$ native woody species were recorded under $P$. juliflora thicket, but 1252 trees ha-1 native species were recorded under non-invaded woodlands. If the present effects of the invasion of $P$. juliflora on native species diversity were to continue coupled with a drier climate, plant diversity of the Afar flora region will be highly affected. As a result the ecosystem services will be under threat. Thus, the participation of all stakeholders and multidisciplinary research approaches should be designed for the management of invaded rangelands to reverse the situation.

\section{Introduction}

Invasive species are either indigenous or exotic species that can heavily colonize a particular habitat [1]. A species is considered an invasive alien species when it spreads beyond its natural area of distribution [2]. Prosopis juliflora (Sw.) DC is among the invasive plant species native to South America, the Caribbean, and Central America [3]. P. juliflora has been introduced intentionally to Ethiopia particularly in the Afar region in the late 1970s for the reclamation of degraded areas in low lands [4-7). Although introduced P. juliflora has been providing a few uses, for instance, fuelwood and dry season fodder in rural areas, the threat posed by it in terms of invasion of fertile agricultural lands and loss of bio-diversity is looming enormously [8]. In the lowlands of Ethiopia, rangelands are subjected to different human and natural impacts. These have in turn facilitated the invasion of undesirable herbaceous weeds and woody plants in rangelands thereby threatening pastoral production systems [9]. Among woody invasions, $P$. juliflora is imposing the most jeopardy 
to arid and semi-arid areas in the east and northeast Ethiopia, particularly in the Afar region $[10,5,11]$.

Land use and land cover changes, competitive ecological advantages, and climate changes are also among the key factors thought to influence the probability of invasion of $P$. juliflora [3, 12]. Use of woody species for fuelwood and construction purposes and overgrazing have also impacts on natural resources $[13,14]$. The seed dispersal mechanism of $P$. juliflora is also the most facilitating process for its invasiveness of the plant. Endozoochory has been recognized as the most important dispersal mechanism in the invasion $P$. juliflora, because their sugary, tasty pods attract animals and because some of their seeds remain intact after passing through some animals' digestive systems [15].

A recent report by Shiferaw et al. [16] revealed that 1.2 million ha of land to have been invaded by $P$. juliflora constituting $12.3 \%$ of the surface area of the Afar region. Due to low moisture requirements and dispersal agents of $P$. juliflora, roadsides, river courses, farmlands, irrigation canals, wetlands, grasslands, conservation areas, and homestead areas are the most severely invaded habitats in the Afar region [17]. P. juliflora is dominating large areas of prime grazing land of the Afar region. Consequently, nutrient-rich palatable grasses, the main feed source for grazers are becoming progressively outcompeted [7].

There is plenty of literature showing both the negative as well as the positive environmental uses of P. juliflora. However, in East Africa and the Afar region of Ethiopia in particular, the problems of $P$. juliflora are outweighing positive ones in the context of ecological, socio-economic, and health aspects [5,11]. It has been noted that $P$. juliflora has a depressing effect on annual compared with perennial plants, especially on grasses in arid lands $[18,19)$. The study by Kahi et al. [20] revealed that standing biomass, frequency, and the cover of understorey plant species to be significantly higher in the open area than under the canopies of $P$. juliflora.

Impacts of $P$. juliflora on diversity studies in the Afar region have been discussed by many researchers such as Berhanu and Tesfaye [4], [16], Kebede [21], Getachew et al. [22], and Tesfaye [23]. However, little is known about the extent of effects posed by P. juliflora on plant diversity, composition, and regeneration of woody species. In this study, we tried to assess the effects of $P$. juliflora invasion levels on (i) the floristic composition and diversity of plant species and (ii) the regeneration potential of native woody species in selected P. juliflora invaded areas of Amibara and Awash Fentale districts of Southern Afar region, Ethiopia. Then, we tested the following hypotheses: (1) native species diversity and composition are not affected by different $P$. juliflora invasion levels, and (2) regeneration patterns of woody species.

\section{Materials and Methods}

\section{Description of the study area}

In this study, two P. juliflora invaded districts from the Southern Afar region namely Awash Fentale and Amibara districts were selected for data collection. The districts were selected based on invasion of $P$. juliflora and existence of non-invaded land use and covers (P. juliflora invasion levels) for comparisons. Then, four sites: Diduba and Kebena from Awash Fentale; and Kurkura and Andido from Amibara district were selected. Amibara district is located in between 741-746 m asl altitudes and 9019'43.83" N latitudes and 40 10'51.6" E longitude, whereas Awash Fentale is located at 700-1000 m asl altitude and $9^{0} 10^{\prime} 00^{\prime \prime} \mathrm{N}$ and $40^{\circ} 03^{\prime} 33^{\prime \prime} \mathrm{E}$ (Figure 1). 


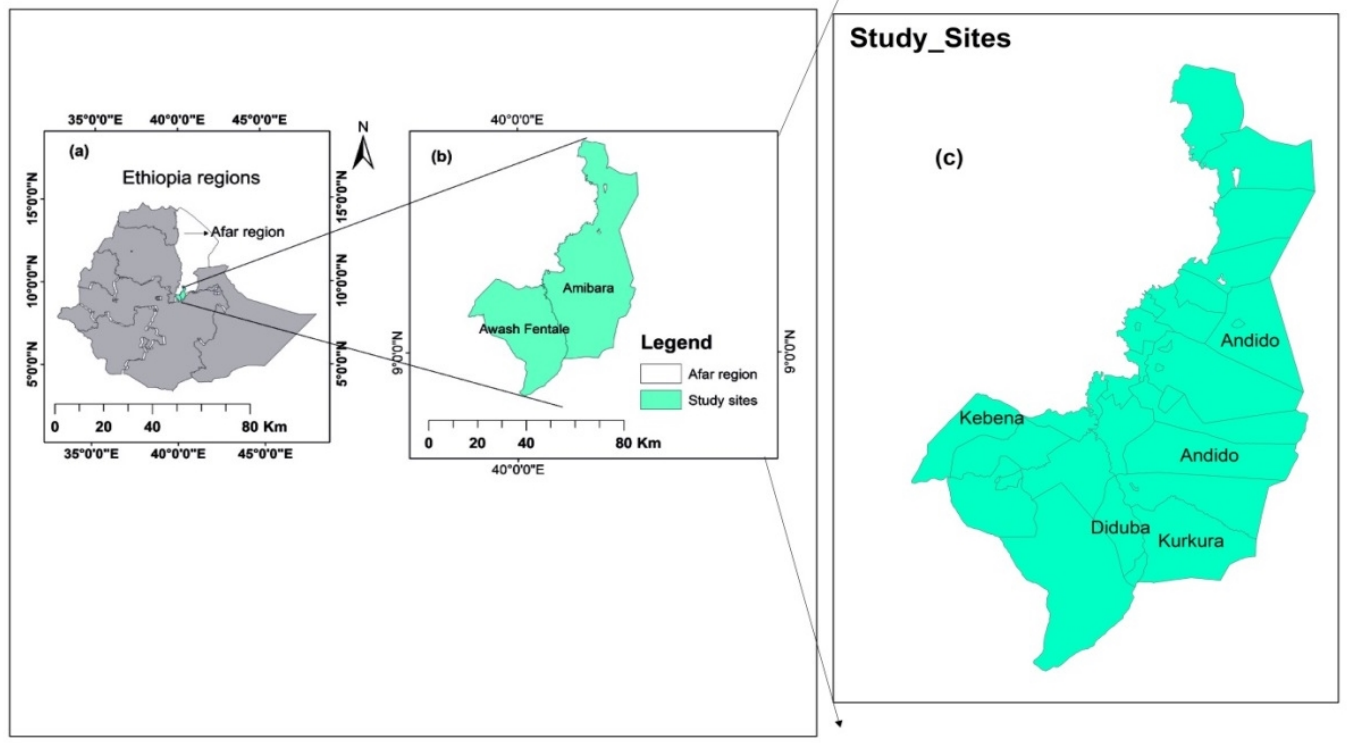

Figure 1. Location of the study area (Afar region) in Ethiopia (a) and location of Amibara District and Awash Fentale District in Afar region (b), and study sites (c).

The texture of the soils was usually sandy and originated from Jurassic and Cretaceous limestone and other sedimentary rocks [24]. According to FAO soil classification and ISRIC-world soil information, the soil of the Afar Floristic Region is Lithic and Eutric leptosols, and Eutric fluvisols. Acacia-Commiphora woodland and bushlands are among the vegetation types in Ethiopia which are characterizing the floristic region [24]. Number of population in Amibara and Awash Fentale were 83, 851, and 40,901, respectively [25]. Ninety percent of Afar people are pastoralists, while the rest are considered agro-pastoralists [26].

\section{Sampling design}

During the preliminary reconnaissance survey, P. juliflora invaded patches and non-invaded lands were selected for vegetation inventory. The sites have been selected based on the severity of invasion by $P$. juliflora and the existence of non-invaded adjacent sites. Moreover, the study sites were stratified into approximately homogeneous units based on the following parameters: such as invasion levels of $P$. juliflora (invasion levels were quantified on number stems of $P$. juliflora in habitats), land use and land cover, and physiography of the sites. Thus, vegetation data were collected from (1) P. juliflora thicket which contained purely P. juliflora stems in the patch, (2) mixed $P$. juliflora with native species in the patch, and (3) non-invaded woodland and open grazing land as control which contained no $P$. juliflora were in the habitat.

Quadrants were laid at different invasion levels to collect vegetation and other environmental variables [27]. For this study, a stratified random sampling technique was used. Those quadrats for habitat categories were selected to assess the variations of $P$. juliflora invasion levels and other environmental factors on vegetation patterns, abundances, and regeneration potentials of woody species. Modified methods of habitat selection were followed: Gairola et al. [28] and Muturi et al. [29]. Thus, a total of 64 quadrats from the study sites i.e. 16 quadrats from each of four $P$. juliflora invasion levels were sampled (Plate 1). 
bioRxiv preprint doi: https://doi.org/10.1101/2021.03.09.434549; this version posted March 9, 2021. The copyright holder for this preprint (which was not certified by peer review) is the author/funder, who has granted bioRxiv a license to display the preprint in perpetuity. It is made available under aCC-BY 4.0 International license.
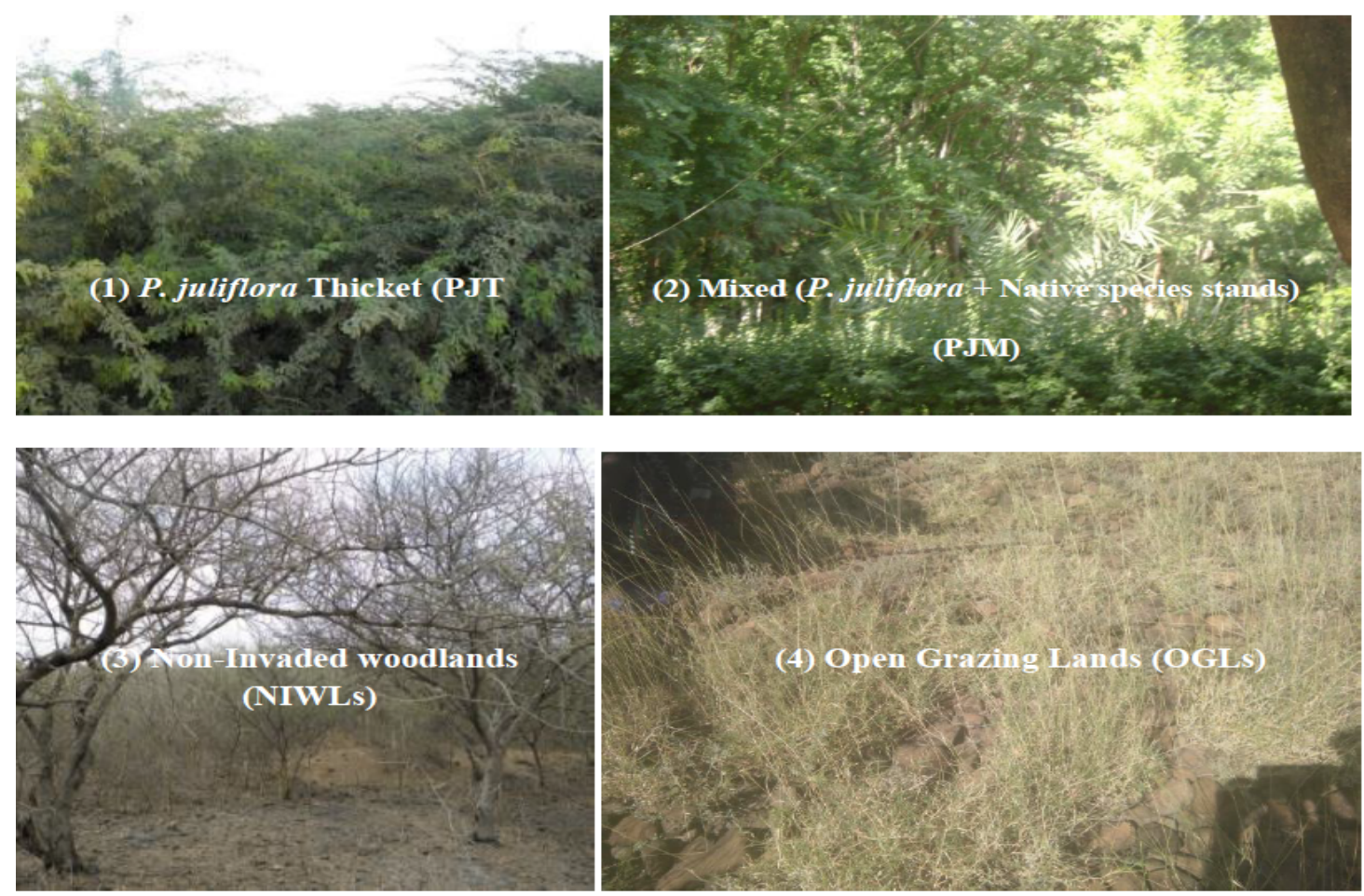

Plate 1. Sample plates for P. juliflora invasion levels/habitats in Afar Floristic Region

Vegetation data were collected under different $P$. juliflora invasion levels using quadrat sizes of $20 \mathrm{~m} \times 20 \mathrm{~m}\left(400 \mathrm{~m}^{2}\right)$ for $P$. juliflora thicket, $P$. juliflora with native species, and non-invaded woodland and open grazing lands. The first quadrat was started randomly, and then the successive quadrats were established using preferential sampling for patches and open grazing lands adjacent to each other.

\section{6}

\section{Data Collection}

Individual woody categorizations were made at a height of less than $1 \mathrm{~m}$ and diameter at stump height (DSH) less than $1 \mathrm{~cm}$ for seedlings. The height 1-2 $\mathrm{m}$ and diameter at breast height (DBH) or diameter at stump height $1-5 \mathrm{~cm}$ for saplings and height greater than $2 \mathrm{~m}$ and DBH/DSH greater than $2 \mathrm{~cm}$ for tree/shrub species were measured. For regenerated seedlings (height less than $1 \mathrm{~m}$ ), only their number was counted and recorded. In each plot, all trees or shrubs were measured and counted. Based on DBH size classes, size class structures were made for each woody species (Figure 3). Cover abundance was also identified and estimated for all growth forms using Maarel [30]. Diameter at breath height (DBH) for trees or diameter at the stump height (DSH) for shrubs was measured in the quadrats to capture all multi-stem in each individual of the shrub. Caliper and hypsometer were used to measure tree/shrub diameter and height respectively.

If a tree was branched at breast height or below, the diameter was measured separately for the branch and then averaged. Any individual with its above-ground stem growing in a cluster for woody plants (shrubs) was counted and measured as a single individual for basal area calculation

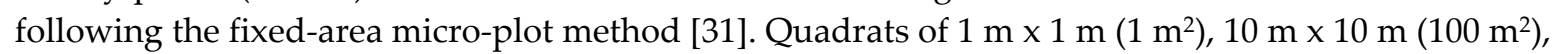
and $20 \mathrm{~m} \times 20 \mathrm{~m}\left(400 \mathrm{~m}^{2}\right)$ were used for recording seedlings/herbaceous, saplings, and tree/shrub

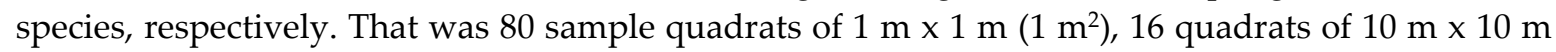
$\left(100 \mathrm{~m}^{2}\right)$, and 16 quadrats of $20 \mathrm{~m} \times 20 \mathrm{~m}\left(400 \mathrm{~m}^{2}\right)$ were laid in each invasion levels.

The presence or absence of plant species was registered by direct counting. Percentage cover (ground cover) of herbaceous plants was estimated from the five subplots of $1 \mathrm{~m}^{2}$ (at four corners and one in the center of the main plot) and then the mean estimates were taken [30]. That is, all grasses and herbaceous within the marked area of the $1 \mathrm{~m}^{2}$ were estimated, recorded, and collected for identification. All quadrats were geo-referenced using GPS for location (coordinates) and 
altitudes; and a clinometer for slopes, hypsometer for the height of trees. Plant specimens were brought and stored in Addis Ababa University's national herbarium for further identification. Plant identification and naming were followed by published flora books of Ethiopia and Eritrea.

\section{Data analysis}

The cover/abundance values of all plant species in each plot were visually estimated using a 1-9 modified scale [27]. Evenness $\left(E^{\prime}\right)$ was calculated from the ratio of observed diversity to maximum diversity following Pielou [29]. Then, deviations from the means were calculated as the standard error.

The diversity of plant species were analyzed using R-software version 3.5.1 for vegetation patterns. Data series were tested for normality and homogeneity of variance. The regeneration status of woody species was determined based on the population size of seedlings, saplings, and adults. Then, all obtained vegetation patterns in terms of diversity indices and regeneration of woody species in different $P$. juliflora invasion levels were subjected to analysis of variance using the General Linear Model of SAS (version 9.0) software [30]. Significant differences among means were separated using Duncan's multiple range tests for effects of $P$. juliflora invasion levels on vegetation patterns and regeneration potential of woody species.

\section{Results}

\section{Invasive effects of $P$. juliflora on floristic composition and structure}

In this study, 157 plant species belonging to 34 families were recorded (Appendix 1). Plant life-form distribution showed high variability among different families. In the study sites, 29 $(18.5 \%)$ plant species belonged to Poaceae, $13(8.3 \%)$ belonged to Fabaceae, and $7(7 \%)$ species each belonged to the families Acanthaceae and Malvaceae.

Among species recorded, 87 (27.4\%) were under non-invaded woodlands, but $70(22 \%)$ were in open grazing lands. The dominant growth form was forbs under P. juliflora thicket, which accounted for 44 (13.8\%) of all growth forms (Figure 2). Results also showed that 17 (5.3\%) grass species were recorded under $P$. juliflora thicket, but $16(5 \%)$ under non-invaded woodlands. Besides, $9(2.8 \%)$ tree species were recorded under $P$. juliflora occurring with native species and $7(2.2 \%)$ tree species in non-invaded woodlands. However, 5 tree species $(1.6 \%)$ were recorded from under $P$. juliflora thicket and open grazing lands each (Figure 2).

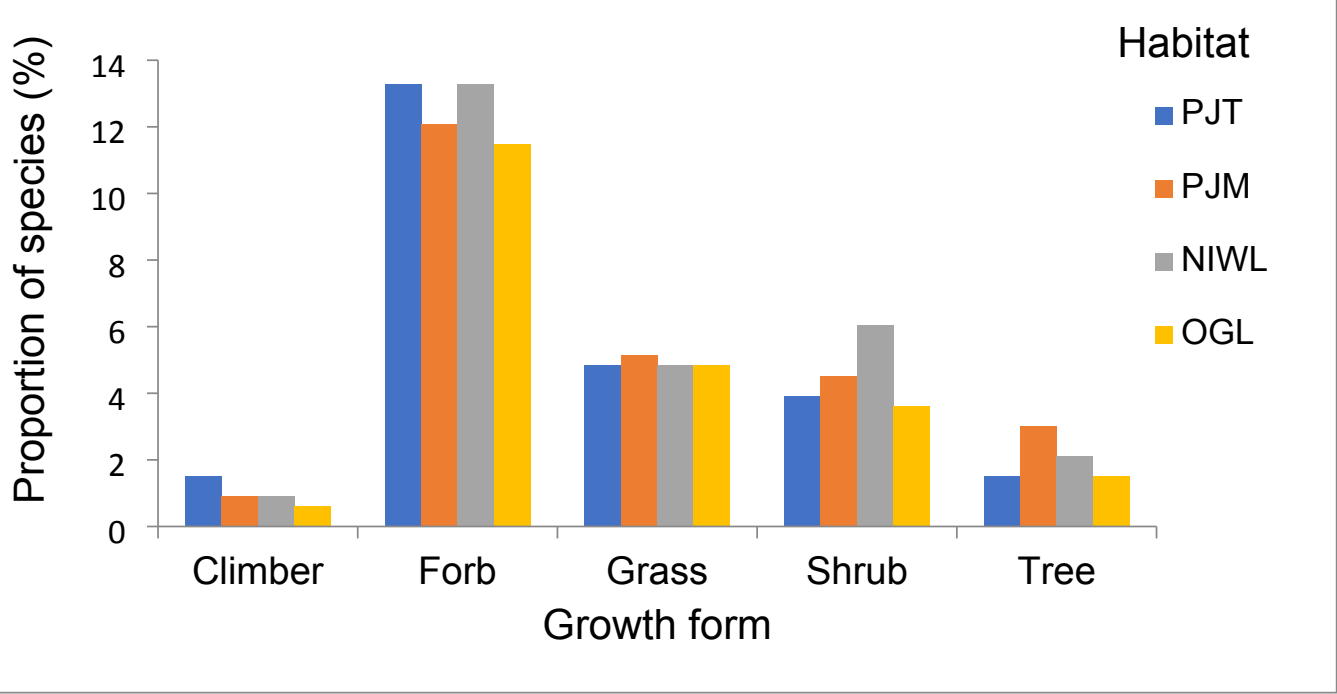

Figure 2. Proportion (\%) of plant species in each habitat (PJT is Prosopis juliflora thicket, PJM is Prosopis juliflora mixed with naïve species, NIWL is non-invaded woodland, OGL is open grazing land). 


\section{Invasion of P. juliflora and plant species diversity}

173

174

175

176

177

178

179

180

As depicted in (Table 1), P. juliflora invasion levels had significantly affected the Shannon diversity index and species richness $(P<0.05)$. However, the $P$. juliflora invasion levels did not affect Shannon evenness $(P>0.05)$. On the other hand, species diversity indices (Shannon diversity index, species richness, and Shannon evenness) did not show significant difference between districts at $P>$ 0.05 (Table 1).

\begin{tabular}{|c|c|c|c|c|c|c|}
\hline Explanatory variable $\times$ Response variable & Source & $\overline{\text { Df }}$ & Sum of squares & Mean square & F-value & Pr $>$ F \\
\hline \multirow{3}{*}{ Habitat $\times \mathrm{H}^{\prime}$} & Model & 3 & 1.86 & 0.62 & 3.74 & 0.016 \\
\hline & Error & 60 & 9.92 & 0.17 & - & - \\
\hline & Corrected total & 63 & 11.77 & - & - & - \\
\hline \multirow{3}{*}{ Habitat $\times \mathrm{R}$} & Model & 3 & 191.42 & 63.81 & 3.52 & 0.020 \\
\hline & Error & 60 & 1086.81 & 18.11 & - & - \\
\hline & Corrected total & 63 & 1278.23 & - & - & - \\
\hline \multirow{3}{*}{ Habitat $\times E^{\prime}$} & Model & 3 & 0.01997 & 0.0067 & 2.41 & 0.076 \\
\hline & Error & 60 & 0.166 & 0.0028 & - & - \\
\hline & Corrected total & 63 & 0.186 & - & - & - \\
\hline \multirow[t]{3}{*}{ District $\times \mathrm{H}^{\prime}$} & Model & 1 & 0.068 & 0.068 & 0.26 & 0.61 \\
\hline & Error & 62 & 15.94 & 0.26 & & \\
\hline & Corrected total & 63 & 16.006 & & & \\
\hline \multirow[t]{3}{*}{ District $\times \mathrm{R}$} & Model & 1 & 0.0 & 0.0 & 0.0 & 1.0 \\
\hline & Error & 62 & 4716.0 & 76.06 & & \\
\hline & Corrected total & 63 & 4716.0 & & & \\
\hline \multirow[t]{3}{*}{ District $\times E^{\prime}$} & Model & 1 & 0.005 & 0.0049 & 0.33 & 0.57 \\
\hline & Error & 62 & 0.948 & 0.0153 & & \\
\hline & Corrected total & 63 & 0.9527 & & & \\
\hline
\end{tabular}

181 The mean value of Shannon diversity index in Table 2 under $P$. juliflora mixed with native species

182 (2.22) and non-invaded woodlands (2.23) were significantly higher than P. juliflora thicket (1.96) and

183 open grazing lands (1.84). Moreover, the average values of species richness in Table 2 under $P$.

184 juliflora mixed with native species (13.94) showed significantly higher than open grazing lands

185 (9.56). Also, the Shannon evenness of non-invaded woodlands (0.87) was significantly higher than

$186 P$. juliflora thicket (0.83) and open grazing lands (0.83) (Table 2).

187 Table 2. Mean values of vegetation patterns for Prosopis invasion levels in South Afar, Ethiopia

\begin{tabular}{llllc}
\hline & \multicolumn{4}{c}{ Prosopis invasion levels } \\
\cline { 2 - 5 } Vegetation patters & PJT $(\mathrm{N}=16)$ & PJM $(\mathrm{N}=16)$ & NIWL $(\mathrm{N}=16)$ & OGL $(\mathrm{N}=16)$ \\
\hline Shannon diversity $(\mathrm{H})$ & $1.96 \mathrm{ab}$ & $2.22 \mathrm{a}$ & $2.23 \mathrm{a}$ & $1.84 \mathrm{~b}$ \\
Richness $(\mathrm{N})$ & $11.50 \mathrm{ab}$ & $13.94 \mathrm{a}$ & $13.44 \mathrm{a}$ & $9.56 \mathrm{~b}$ \\
Shannon evenness $\left(\mathrm{E}^{\prime}\right)$ & $0.83 \mathrm{a}$ & $0.86 \mathrm{a}$ & $0.87 \mathrm{a}$ & $0.83 \mathrm{a}$ \\
\hline \multicolumn{5}{c}{} \\
\hline Vegetation patters & District \\
\hline Shannon diversity $(\mathrm{H})$ & Awash Fentale $(\mathrm{N}=32)$ & Amibara (N=32) \\
Richness $(\mathrm{N})$ & $1.96 \mathrm{a}$ & $1.90 \mathrm{a}$ \\
\end{tabular}


Shannon evenness ( $\left.E^{\prime}\right)$

$0.49 \mathrm{a}$

$0.47 \mathrm{a}$

188 Notice: $\mathrm{N}=$ Number of individuals/species richness per $400 \mathrm{~m}^{2}$ ).

Invasion of P. juliflora and size class structures of woody species

190 As can be seen from the result in (Table 4) tree, saplings and seedlings are shown to be statistically 191 not affected by the invasion of $P$. juliflora at the different invaded habitats $(P>0.05)$. The lowest 192 total densities of trees were recorded under P. juliflora thicket (102 stems/ha). But, the highest total 193 densities of trees were recorded under non-invaded woodlands (1252 stems/ha). Moreover, the 194 highest total density of seedlings was recorded under $P$. juliflora mixed with native species (358 195 stems/ha). However, the lowest total densities of seedlings were recorded under $P$. juliflora thickets 196 (153 stems/ha) (Table 4).

Table 3. General Linear Model showing the effects of $P$. juliflora invasion levels on regeneration status of woody species at Amibara and Awash Fentale districts, Ethiopia.

\begin{tabular}{ccccccc}
\hline Response variables & Source & Df & Sum of squares & Mean square & F-value & Pr $>$ F \\
\hline Habitat $\times$ Trees & Model & 2 & 36907.7 & 18454 & 0.94 & 0.41 \\
& Error & 21 & 410318.9 & 19539 & - & - \\
& Corrected total & 23 & 447226.7 & & & \\
\hline Habitat $\times$ Saplings & Model & 2 & 32.66 & 16.33 & 0.71 & 0.49 \\
& Error & 1592 & 36640.01 & 23.01 & - & - \\
& Corrected total & 1594 & 36672.67 & - & - & - \\
\hline Habitat $\times$ Seedlings & Model & 2 & 69.28 & 34.64 & 1.06 & 0.35 \\
& Error & 1592 & 51796.23 & 32.53 & - & - \\
& Corrected total & 1594 & 51865.51 & - & - & - \\
\hline
\end{tabular}
with native species, NIWL is non-invaded woodlands, stems/ha).

\begin{tabular}{cccc}
\hline \multirow{2}{*}{ Growth Stages } & \multicolumn{3}{c}{ Habitat } \\
\cline { 2 - 4 } & PJT & PJM & NIWL \\
\hline Trees & $102 \mathrm{a}$ & $585 \mathrm{~b}$ & $1252 \mathrm{~b}$ \\
Saplings & $151 \mathrm{a}$ & $334 \mathrm{~b}$ & $324 \mathrm{c}$ \\
Seedlings & $153 \mathrm{a}$ & $358 \mathrm{~b}$ & $242 \mathrm{c}$ \\
\hline
\end{tabular}

Results showed that the pattern of population structure for a given species can be roughly grouped in one of four basic types: Type I (inverted J-shape), Type II (bell-shaped type), Type III (Jshape), and Type IV (U-shaped). Type I is a pattern in which a diameter size class distribution displays a greater number of smaller seedlings than large ones. Type II is characteristic of species that show discontinuous, irregular, and or periodic recruitment. Type III reflects a species whose regeneration is severely limited. Type IV is characteristic of species that show a lower number of saplings or mid-class distribution than seedlings and trees.

The results in Figure 3 ( $3 \mathrm{~b} \& \mathrm{f})$ showed that the population of P. juliflora and Acacia tortilis 
bioRxiv preprint doi: https://doi.org/10.1101/2021.03.09.434549; this version posted March 9, 2021. The copyright holder for this preprint (which was not certified by peer review) is the author/funder, who has granted bioRxiv a license to display the preprint in perpetuity. It is made available under aCC-BY 4.0 International license.

Furthermore, in Figure ( $3 \mathrm{~d} \& \mathrm{j})$ the population of $C$. rotundifolia, under non-invaded woodlands, and Salvadora persica L. under $P$. juliflora mixed with native species were showed the regeneration patterns of inverted J-shape (Type I). On the other hand, the population of A. mellifera, S. persica and A. tortlis under NIWL; and P. juliflora, G. tenax, A. oerfota, A. senegal, A. mellifera and C. rotundifolia under $P$. juliflora thickets; and $A$. nilotica under non-invaded wood lands and woody species like $A$. mellifera, A. oerfota, A. tortilis, G. tenax, S. persica, C. rotundifolia under open grazing lands resembled the limited regeneration patterns of J-shape (Type III) in the study areas (Figure 3, b, d, g, h, i \& j).
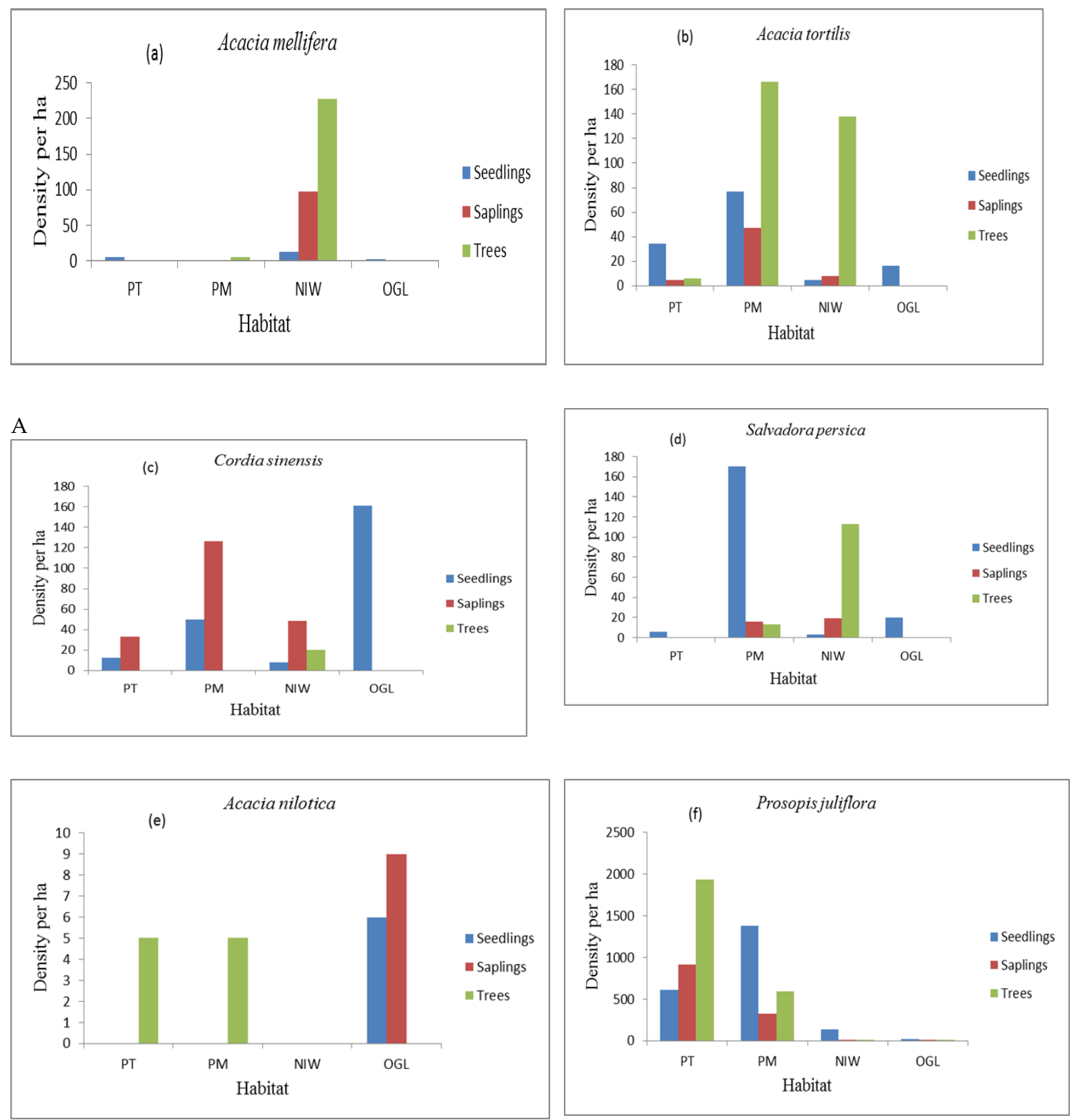
bioRxiv preprint doi: https://doi.org/10.1101/2021.03.09.434549; this version posted March 9, 2021. The copyright holder for this preprint (which was not certified by peer review) is the author/funder, who has granted bioRxiv a license to display the preprint in perpetuity. It is made available under aCC-BY 4.0 International license.
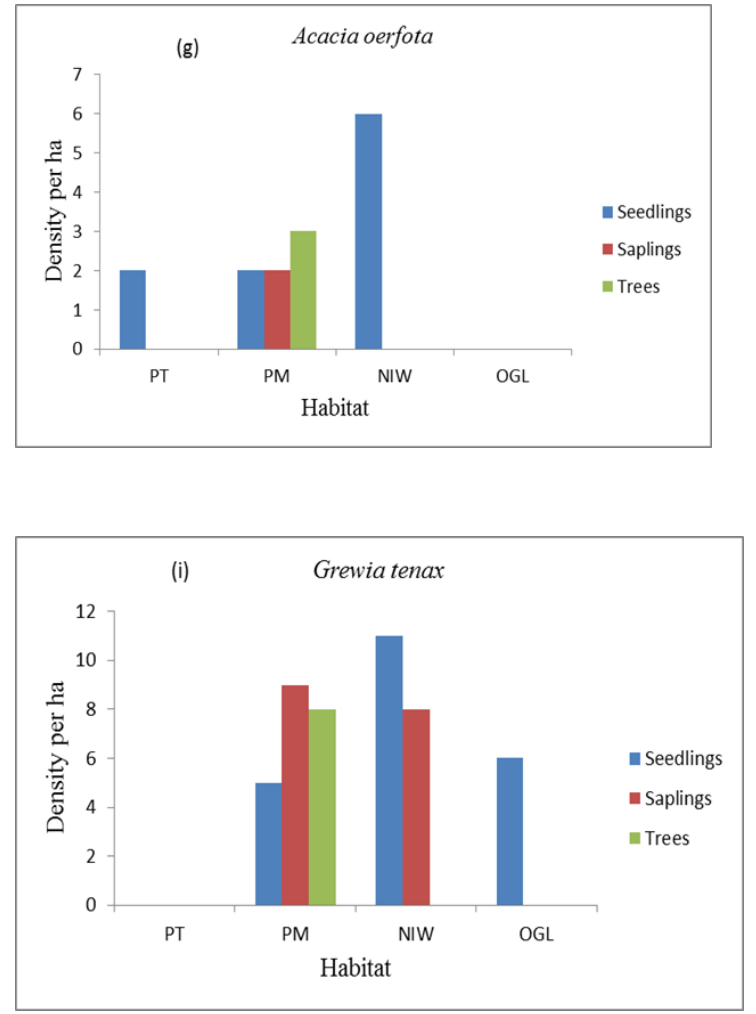
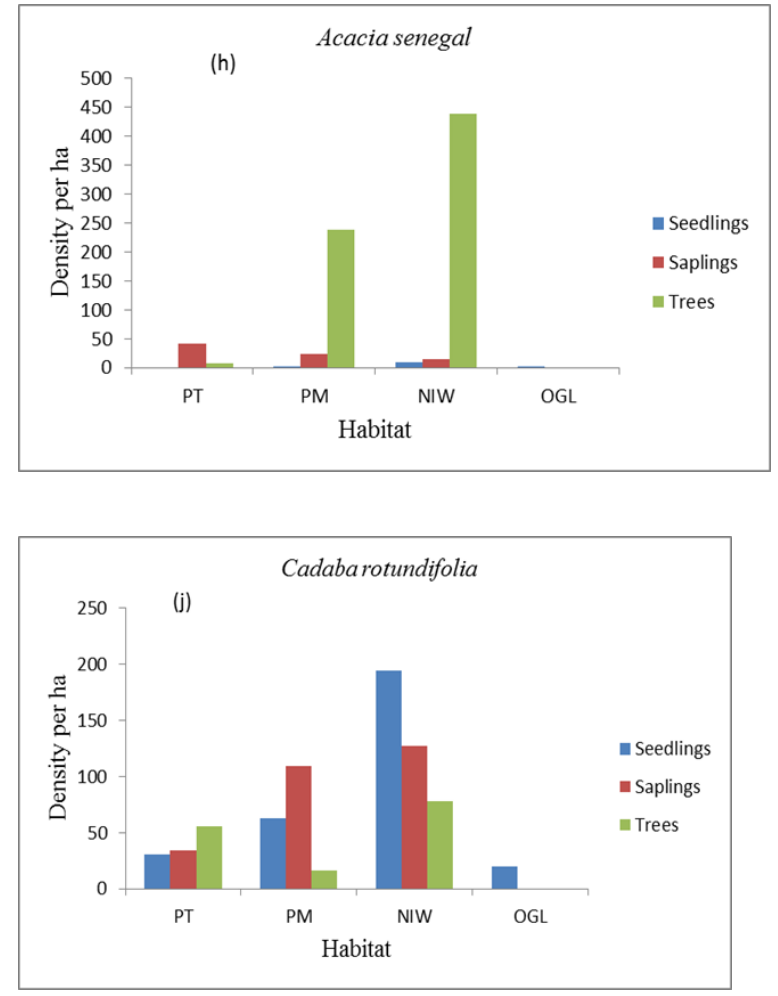

Figure 3 a-j. Size class structures of ten species population in each habitat (PT $=\boldsymbol{P}$. juliflora thicket stands, PM=P. juliflora with native species stands, NIW = non-invaded woodland, OGL = open grazing land).

\section{Discussion}

\section{P. juliflora and floristic composition}

In this study, the number of families identified was comparable with research reported by Aggarwal [33] from the pre-urban region of India and findings by Demissie [34] in Awash National Park in Ethiopia. Other findings by Mukherjee et al. [32] showed that both the number of species and families were lower than the number of families recorded in the present study.

The species richness under the canopy of $P$. juliflora, in this study, was lower compared with those reported by Patel et al. [36] for Delhi, Gujarat, and Rajasthan in India. Our study also revealed that the number of species under $P$. juliflora thicket was higher than that of the number of species under the P. juliflora thicket on Delhi ridge of India [37]. Similar trends on the number of associated species were also observed in sites with a lower density of $P$. juliflora under $P$. juliflora with native species and outside (non-invaded woodlands) canopies in UAE [38].

The presence of more climbers under P. juliflora thicket compared to other habitats might be due to the presence of woody species that help the climbers as support. The trees in the habitats also serve as safety factors to resist a range of natural factors, particularly high winds [39].

A higher number of forb species were also observed under $P$. juliflora thicket than other habitats. The availability of forbs contributes to suitable resource islands which had out-competed other species under the thicket of $P$. juliflora canopies [40,41]. On the other hand, grass species were higher under $P$. juliflora with native species than other habitats. In these particular cases, $P$. juliflora invasion might affect the growth of grasses due to the inhibition of light penetration and allelopathic chemicals under the thicket of $P$. juliflora [18]. In the present study, the decline in tree 
forms under the habitats of non-invaded woodlands could be attributed to anthropogenic impacts (i.e., exploitation of trees for firewood and construction) and browsing [13,42,43].

\section{P. juliflora invasion and species diversity}

Species diversity has been recognized as an important component of the sustainable development of $P$. juliflora with native species [26]. This is because of ecosystems with diverse species resilient for the competition of resources with $P$. juliflora. Species diversity was lower both under open grazing lands (1.84) and P. juliflora thicket (1.96) compared to P. juliflora mixed with native species (2.22) and non-invaded woodlands (2.23) habitats. The reason might be disturbance intensities under open grazing lands and effects of canopy $P$. juliflora which had dominated other native species. The species diversity under non-invaded woodlands and P. juliflora mixed with native species stands were comparable to the report made by Zerga [44] in Awash National Park of Ethiopia and by Aggarwal, [33] at Peri-urban Region in India.

Other findings such as those of Kumar and Mathur [45] indicate higher species diversity than that of the present study. The reason might due to grazing impacts and moisture stress in the study areas. In the present study, the average values of species richness ranged from open grazing lands (9.6) to $P$. juliflora with native species (13.9). The higher the species richness under $P$. juliflora with native species and non-invaded woodlands contributes to anthropogenic impacts, grazing, and disturbance intensities, and the decline of $P$. juliflora invasions and its canopy effects which $P$. juliflora is an aggressive invader, canopy effects were consistently and strongly negative on species richness [46]. In this study, the mean values of species richness were similar under $P$. juliflora with native species to $P$. juliflora invaded forest and arid grazing lands at the Gujarat state of India, but the mean values of species richness in our study were higher under $P$. juliflora with native species and P. juliflora thicket habitat than P. juliflora invaded areas of Reserve Vidis and open grazing of arid grazing lands at Gujarat state of India [45]. In all of the habitats of this study on the contrary, we found lower species richness than Aggarwal [33] in a Peri-urban Region of India during rainy, winter and, summer seasons.

\section{P. juliflora invasion and size class structures of woody species}

Quantitative analysis of the regeneration status of woody species recorded in this study may provide baseline information to design and formulate conservation and management strategies for $P$. juliflora dominated woodlands. The regeneration status of woody species of any vegetation is determined based on densities of seedlings and saplings [47]. The ratio of various age groups in a population determines the reproductive status of the population and indicates the future course [48].

In this study, the highest species diversity of trees, saplings, and seedlings were recorded under $P$. juliflora thicket, $P$. juliflora with native species stands, and under non-invaded woodlands in that order. The decline in the number of trees under non-invaded woodlands is accounted for by the effects of human impacts, livestock grazing, and disturbance intensities [13]. Besides, the increase in the density of individual stems in the form of the tree and seedling stages under non-invaded woodlands and $P$. juliflora mixed with native species stands might be due to its allopathic substances that would inhibit the growth of associated native species [3,49,22].

Due to illegal cutting, the abundance of tree species under non-invaded woodlands and $P$. juliflora with native species stands were similar to the research findings by Patel et al. (2012) in western Kachchousehold of Gujarat in India. However, our findings were contrary to results reported by Muturi et al. [29] in which the distribution of trees under P. juliflora with native species stand was higher than non-invaded woodlands and P. juliflora thicket in the Turkwel riverine forest 
of Kenya. The reason could be the variations in the management of vegetation types and age of $P$. juliflora variations which might not also affect native species under the $P$. juliflora with native species stands in Kenya.

\section{P. juliflora invasion levels and size class structures of selected woody species}

Regeneration is a crucial phase of vegetation management as it maintains the desired species composition and stocking and can be predicted by the structure of the population [50]. Different categories of regeneration status were designated following [51,50].

A. mellifera under $P$. juliflora thicket and $P$. juliflora mixed with native species stands, $A$. oerfota under $P$. juliflora thicket and non-invaded wood lands, G. tenax, A. senegal, A. nilotica and C. rotundifolia under open grazing lands, and $P$. juliflora under non-invaded woodlands and open grazing lands, and G. tenax under non-invaded woodlands showed new regeneration categories. Whereas C. rotundifolia and P. juliflora under $P$. juliflora thicket, A. mellifera and A. senegal under $P$. juliflora mixed with native species stands, and A. senegal, S. persica under non-invaded woodlands, C. rotundifolia and G. tenax under $P$. juliflora thicket showed fair regeneration categories.

Furthermore, S. persica and C. rotundifolia under non-invaded woodlands showed good regeneration in the study areas. In contrast to our findings, the findings of Endris et al. [52] showed that $P$. juliflora under $P$. juliflora mixed with native species stands and A. mellifera under non-invaded woodlands showed good regeneration profiles in the Hallideghie wildlife reserve, Northeast Ethiopia. Furthermore, the density of seedlings for $P$. juliflora and $A$. tortilis under $P$. juliflora mixed with native species stands, non-invaded woodlands, and P. juliflora thicket also showed inconsistent patterns of densities in comparison to reports by Muturi et al. [29] that show higher densities in comparison to trees and saplings.

\section{Conclusions}

It has been demonstrated in this study that species diversity decreased under grazed lands and $P$. juliflora thicket. $P$. juliflora invasion thus remains a threat to the overall native species diversity and eventually harming the rangelands and livestock production. Under Prosopis juliflora thicket, higher DBH classes of native woody species were dominated by P. juliflora. But, lower DBH size classes (seedlings) were recorded under $P$. juliflora mixed with native species stands implied that the effects of $P$. juliflora on the individuals declined. Thus, appropriate silvicultural techniques (e.g. thinning) of $P$. juliflora should be practiced to lessen the invasiveness of the species. Further studies about the phenology of $P$. juliflora are vital to know the seasons of seed dispersal to manage its invasiveness. Furthermore, the regional natural resource office should provide alternative energy sources such as solar radiation and P. juliflora based biogas plants to alleviate the devastation of other indigenous woody species in the region. Thus, long-term effects of $P$. juliflora species on soil seed bank, soil properties, the progress of $P$. juliflora on environmental threats, and its socioeconomic impacts on other invaded areas should also be investigated in the future.

Author Contributions: All authors have equally contributed to the manuscript

\section{Conflicts of Interest: No conflicts among authors for interests}

332 Acknowledgments: The authors are thankful to Arba Minch and Addis Ababa Universities for 333 financing the project. The first author special thanks Afar pastoral communities for their 334 cooperation and assistance during data collection. Department of natural resources management in pastoral and agro-pastoral districts of the Amibara and Awash Fentale districts are acknowledged for material and human resources assistance during site selection and data collection. All the members of the National Herbarium of Addis Ababa University are also appreciated for their facilitation of materials in the herbarium for plant identification. 


\section{References}

1. Ethiopian Biodiversity Institute (EBI). Ethiopian's fifth national report to the conservation biodiversity, Addis Ababa, Ethiopia, 2014. pp. 1-136, https://nbsapforum.net > sites > default > files.

2. Richardson, D.M.; Binggeli, P.; Schroth, G. Invasive agroforestry trees: problems and solutions, 2003, 15, 371-396.

3. Pasiecznik, N.M.; Felker, P.; Harris, P.J.C.; Harsh, L.N.; Cruz, G.; Tewari., J.C.; Cadoret., K; Maldonado, L.J. The Prosopis juliflora - Prosopis pallida Complex: A Monograph, HDRA, Coventry, 2001, UK. pp.172.

4. Berhanu, A.; Tesfaye, G. The Prosopis juliflora Dilemma, Impact on Dryland Biodiversity and Some Controlling Methods. Journal of the Dry Lands, 2006, 1, 158-164.

5. Abebe, Y. Ecological and Economic Dimensions of the Paradoxical Invasive Species- Prosopis juliflora and Policy Challenges in Ethiopia. Journal of Economics and Sustainable Development 2012, 3, 62-70.

6. Haji, J.; Mohammed, A. The economic impact of Prosopis juliflora on agro-pastoral households of Dire Dawa Administration, Ethiopia. African Journal of Agricultural Research 2013, 8, 768-779.

7. Ayanu, Y.Z.; Anke, J.; Detlef, M. Ecosystem engineer unleashed: Prosopis juliflora threatening ecosystem services? Regional Environmental Change 2015, 15, 155-167.

8. FAO. Invasion of Prosopis juliflora in India, In Problems posed by the introduction of Prosopis juliflora species in selected countries, Italy Rome, 2006. pp.13.

9. Dalle, G.; Maass, B.L.; Isselstein, J. Encroachment of woody plants and its impact on pastoral livestock production in the Borana lowlands, southern Oromia, Ethiopia. Afr. J. Ecol. 2006, 44, 237-246.

10. Shiferaw, H.; Teketay, D.; Nemomissa, S. Some Biological Characteristics That Foster the Invasion of Prosopis juliflora

(Sw.) DC in Middle Awash Rift Valley Area, North-Eastern Ethiopia. Journal of Arid Environments 2004, 58, 135-154.

11. Shiferaw, W.; Demissew, S.; Bekele, T. Invasive alien plant species in Ethiopia: ecological impacts on biodiversity a review paper. Int J Mol Biol. 2018, 3, 171-178.

12. Shiferaw, W.; Demissew, S.; Bekele, T.; Aynekulu, E. Effects of Prosopis juliflora invasions on land use/cover change in the South Afar region, Northeast Ethiopia. Advance Research Journal of Multidisciplinary Discoveries 2019b, 34, 26-43.

13. Tsegaye, D.; Moe, R.S.; Vedeldc, P.; Aynekulu, E. Land-use/cover dynamics in Northern Afar rangelands, Ethiopia. Agriculture, Ecosystems and Environment 2010, 139, 174-180.

14. Islam, K.; Jashimuddin, M.; Nath.; B.; Nath, K.T. Land use classification and change detection by using multi-temporal remotely sensed imagery: The case of Chunati wildlife sanctuary, Bangladesh. The Egyptian Journal of Remote Sensing and Space Sciences 2018, 21, 37-47.

15. Abbas, M.; Mancilla-Leyt, J.M.; Castillo, J.M. Can camels disperse seeds of the invasive tree Prosopis juliflora? Weed Research 2018, 58, 221-228.

16. Shiferaw, H.; Schaffner, U.; Bewket, W.; Alamirew, T.; Zeleke, G.; Teketay, D.; Eckert, S. Modeling the current fractional cover of an invasive alien plant and drivers of its invasion in dryland ecosystems. Scientific reports 2019a, 9, 1576. 
17. Abbas, A.M.; Rubio-Casal, A.E.; Cires, A.D.; Grewell, B.J.; Castillo, J.M. Differential tolerance of native and invasive tree seedlings from arid African deserts to drought and shade. South African Journal of Botany 2019, 123, 228-240.

18. El-Keblawy, A. Impacts of Native and Exotic Prosopis Species on Native Plants in Arid lands of the $U A E$, International Conference on Ecology, Agriculture and Chemical Engineering (ICEACS'2012) December 18-19, 2012, Phuket (Thailand).

19. Tiedemann, A.R. Effect of Mesquite (Prosopis juliflora) Trees on Herbaceous Vegetation and Soils in the Desert Grassland, Ph.D. Dissertation, University of Arizona, 1970, University Microfilms, Inc., Ann Arbor, Michigan.

20. Kahi HC (2004). The Effects of Prosopis juliflora (DC) Hyne and Acacia tortilis (Forsk) Trees on Understorey Plant Species and Soil Properties on Njemps Flats, Baringo District, Kenya.; MSc thesis, University of Nairobi, Kenya.

21. Kebede, A.T. "Sustaining the Allideghi Grassland of Ethiopia: Influence of Pastoralism and Vegetation Change", All Graduate Theses and Dissertations, Paper, 2009, 309, http://digitalcommons.usu.edu/etd/309.

22. Getachew, S.; Demissew, S.; Woldemariam, T. Allelopathic Effects of the Invasive Prosopis juliflora (Sw.) DC on Selected Native Plant Species in Middle Awash, Southern Afar Rift of Ethiopia. Management of Biological Invasions 2012, 3, 105-114.

23. Tesfaye, S.K. Impact of Prosopis juliflora L. (Fabaceae) on Plant Biodiversity at Alledeghi Wildlife Reserve and Surrounding Local Community, Ethiopia. MSc thesis, 2015, Addis Ababa University.

24. Friis, I.; Demissew, S.; Breugel, P.V. Atlas of potential vegetation of Ethiopia. The Royal Danish Academy of Sciences and Letters, Biologiske Skrifter, 2010, 58, pp.1-315.

25. Central Statistical Agency (CSA). (2013). Population Projection of Ethiopia for All Regions at district Level, Addis Ababa, Ethiopia.

26. Wakie, T.; Paul, H.E.; Jarnevich, S.C.; Laituri, M. Mapping Current and Potential Distribution of Non- Native Prosopis juliflora in the Afar Region of Ethiopia. Plos One, 2014, 9, e112854.

27. Kent, M.; Coker, P. Vegetation description and analysis: A practical approach, England, 1992, pp. 97

28. Gairola, S.; Sharma, C.M.; Ghildiyal, S.K.; Suyal, S. Regeneration dynamics of dominant tree species along an altitudinal gradient in moist temperate valley slopes of the Garhwal Himalaya. Journal of Forestry Research 2012, 23, 53-63.

29. Muturi, G.M.; Poorter, L.; Mohren, G.M.J.; Kigomo, B.N. Ecological impact of Prosopis juliflora species invasion in Turkwel riverine forest, Kenya. Journal of Arid Environments 2013, 92, 89-97.

30. Maarel, E. Transformation of Cover Abundance in Phytosociology and its Effects on Community Similarity. Vegetation 1979, 39, 97-114.

31. Chojnacky, D.C.; Milton, M. Measuring Carbon in Shrubs, Field Measurements for Forest Carbon Monitoring, In Hoover C.M. (ed.), Springer Science+ Business Media B.V., 2008, pp. 45-72.

32. Pielou, E.C. Species diversity and pattern diversity in the study of ecological succession. J. Theor. Biol 1966, 10, 370-383.

33. Aggarwal, S. Biodiversity and Vegetation Dynamics of a Grazing land in a Peri-urban Region of India. International Journal of Environmental Biology 2012, 2, 74-80.

34. Demissie, H, Invasion of Prosopis juliflora (Sw.) DC. in Awash National Park and Its Impact on Plant Species Diversity and Soil Characteristics.; MSc thesis, 2009, Addis Ababa University, Ethiopia. 
35. Mukherjee, A.; Dilip, A.V.; Nagaraj, H.K. Invasive Prosopis juliflora replacing the Native Floral Community over three decades: a case study of a World Heritage Site, Keoladeo National Park, India. Biodiversity Conservation, 2017, 1-18.

36. Patel, R.M.; Kumar, A.; Dabgar, Y.B. Structure and composition of woody vegetation in western Kachchh, Gujarat. Journal of Biodiversity and Ecological Sciences, 2012, 2, 115-124.

37. Naudiyal, N.; Schmerbeck, J.; Gartner, S. What influences the plant community composition on Delhi ridge? The role played by Prosopis juliflora and anthropogenic disturbances. Tropical Ecology 2017, 58, 33-43.

38. El-Wahab, R.H.A.; Al-Rashed, A.R.; Al-Dousari, A. Influences of Physiographic Factors, Vegetation Patterns, and Human Impacts on Aeolian Landforms in Arid Environment. Arid Ecosystems, 2018, 8, 97-110.

39. Wainwright, S.A.; Biggs, W.D.; Currey, J.D.; Gosline, J.M. Mechanical design in organisms. New York, USA: 1976, John Wiley.

40. Tiessen, H.; Menezes, R.S.C.; Salcedo, I.H.; Wick, B. Organic Matter Transformations and Soil Fertility in a Tree Pasture in Semiarid NE Brazil. Plant and Soil 2003, 252, 195-205.

41. Kahi, C.H.; Ngugi, R.K.; Mureithi, S.M.; Ngethe, J.C. The Canopy Effect of Prosopis juliflora (DC.) and Acacia tortilis (Hayene) Trees on Herbaceous Plants Species, and Soil Physico-chemical Properties in Nejemps Flats, Kenya. Tropical and Subtropical Agro-ecosystems 2009, 10, $441-449$.

42. Majumdar, K.; Datta, B.K. Effects of anthropogenic disturbances on vegetation diversity and structure: a case study in the remnant forests surrounding the village ecosystems of Tripura, Northeast India. Chinese. Journal of Population Resources and Environment 2015, 1-10.

43. Malik, A.Z.; Bhatt, A.B. Regeneration status of tree species and survival of their seedlings in Kedarnath Wildlife Sanctuary and its adjoining areas in Western Himalaya, India. Tropical Ecology 2016, 57, 677-690.

44. Zerga, B. Degradation of Rangelands and Rehabilitation efforts in Ethiopia: The case of Afar rangelands. Journal of Advances in Agricultural Science and Technology 2015, 3, 81-94.

45. Kumar, S.; Mathur, M. Impact of invasion by Prosopis juliflora on plant communities in arid grazing lands. Tropical Ecology 2014, 55, 33-47.

46. Kaur, R.; Gonzales, W.L.; Llambi, L.D.; Soriano, P.J.; Callaway, R.M., et al. Community Impacts of Prosopis juliflora Invasion: Biogeographic and Congeneric Comparisons. PLoS ONE 2012, 7, e44966. doi:10.1371/journal.pone.0044966.

47. Singh, S.; Malik, Z.A.; Sharma, C.M. Tree species richness, diversity, and regeneration status in different oak (Quercus spp.) dominated forests of Garhwal Himalaya, India. Journal of Asia-Pacific Biodiversity 2016, 9, 293-300.

48. Singh, C.; Suman, P.R.; Suman, V. District organization, ecological distribution, and variety of trees and shrubs in chosen regions of Branwar Forest. African Journal of Ecology and Ecosystems 2014, 1, 037-041.

49. El-Keblawy, A.; Al-Rawai, A. Impacts of the invasive exotic Prosopis juliflora (Sw.) D.C. on the native flora and soils of the UAE. Plant Ecology 2007, 190, 23-35. 
51. Pokhriyal, P.; Uniyal, P.; Chauhan, D.S.; Todaria, N.P. Regeneration status of tree species in the forest of Phuket and Pathri Rao watersheds in Garhwal Himalaya. Current Science 2010, 98, 171-175.

52. Endris, A.; Seid, A.; Asefa, A. Structure and regeneration status of woody plants in the 